\title{
Identifikasi Keterdapatan Airtanah Dengan Electromagnetic Very Low Frequency (EM-VLF) di Non Cekungan Airtanah Kecamatan Ungaran Timur
}

\author{
Erik Febriarta ${ }^{1,3^{*}}$, Setyawan Purnama ${ }^{2}$ \\ ${ }^{1}$ Magister Pengelolaan Pesisir dan Daerah Aliran Sungai, Fakultas Geografi, Universitas Gadjah \\ Mada, Yogyakarta \\ ${ }^{2}$ Fakultas Geografi, Universitas Gadjah Mada, Yogyakarta \\ ${ }^{3}$ Palwa Karya, www.Palawakaya.co.id., Yogyakarta
}

\begin{abstract}
Abstrak
Airtanah merupakan seluruh air yang berada di bawah permukaan tanah yang berada pada zona jenuh air. Keterdapatan airtanah dapat ketahui keberadaannya dengan metode geofisika. Metode geofiska berdasarkan elektromagnetik memiliki keunggulan untuk merambatkan gelombang pantul relatif lebih dalam dibanding metode geofiska yang lain. Hal tersebut dikarenakan oleh sifat geolmbang dengan rentang 0,2-30 kHz atau sepanjang hingga $20 \mathrm{~km}$, jika dipancarkan (induksi) ke dalam tanah, sehingga mendapatkan sensitivitas terhadap setiap material lapisan batuan lebih dalam dengan satuan pengukuran nilai konduktivitas. Berdasarkan keunggulan tersebut induksi yang dalam, maka tujuan dari penelitian ini adalah untuk mengetahui keterdapatan airtanah di daerah non Cekungan Airtanah (Non CAT) dengan keberadaan airtanah yang relatif dalam, dengan metode Electromagnetic Very Low Frequency (EM-VLF). Berdasarkan hasil penelitian menunjukkan bahwa 6 dari 35 titik pengukuran tidak ditemukan airtanah. Kedalaman airtanah rata-rata berada pada kedalaman $10 \mathrm{~m}$ dengan potensi debit rata-rata $1 \mathrm{~m}^{3} / \mathrm{jam}(0,27$ liter/detik) pada Non CAT bagian utara, dengan penyusun litologi akuifer batupasir perselingan lempung. Kedalaman rata-rata pada Non CAT bagian selatan adalah 25 $\mathrm{m}$ dengan potensi debit rata-rata $3 \mathrm{~m}^{3} / \mathrm{jam}(0,83$ liter/detik). Litologi akuifer bagian selatan tersusun atas batuanbeku perselingan pasiran. Secara keseluruhan nilai tersebut masuk kedalam kelas debit kecil $(<0,55$ l/detik) dengan akuifer bersifat lokal.
\end{abstract}

Kata kunci: airtanah; debit; electromagnetic very low frequency; non cekungan airtanah Ungaran Timur

\begin{abstract}
Groundwater constitutes all subterranean water in saturated zones. Geophysical methods are among the extensively used techniques to assess groundwater availability. The electromagnetic ones reportedly propagate reflection waves deeper than the other geophysical methods. If emitted into the ground (induction), waves in the range of 0.2-30 kHz (a distance of up to $20 \mathrm{~km}$ ) will be able to obtain the sensitivity of materials in every rock layer, with a measurement unit similar to conductivity. Hence, this study, factoring in the advantages of such deep induction, examined non-groundwater basins for the availability of relatively deep groundwater using the very low-frequency electromagnetic (VLFEM) method. The resulting resistivity values indicated that groundwater did not exist in 6 of 35 measurement points. In the non-groundwater basin on the northern side of the district, groundwater had an average depth of $10 \mathrm{~m}$ and a mean discharge potential of $1 \mathrm{~m}^{3} / \mathrm{hr}(0.27 \mathrm{l} / \mathrm{s})$, with aquifers lithologically composed of sandstones interspersed with claystone. Meanwhile, the one on the south had, on average, a depth of $25 \mathrm{~m}$ and a discharge potential of $3 \mathrm{~m}^{3} / \mathrm{hr}(0.83 \mathrm{l} / \mathrm{s})$, with aquifers lithologically composed of igneous rocks interspersed with sandstone. Overall, these figures show categorically small discharge $(<0.55 \mathrm{l} / \mathrm{sec})$ with local aquifers.
\end{abstract}

Keywords: groundwater; discharge; very low-frequency electromagnetic; East Ungaran nongroundwater basin

\footnotetext{
*Korespondensi: e.febriarta@gmail.com
} 


\section{PENDAHULUAN}

Airtanah merupakan kebutuhan dasar untuk hidup manusia dan makhluk hidup disekitaranya. Keterdapatan air tanah didasarkan atas media keterdapatannya, terdapat di rongga antar butir batuan, sehingga dapat menyimpan dan dilolosakan air tanah (Todd and Mays, 2005 dan Fetter, 2014; Purnama dkk, 2019). Definisi tersebut dapat disebut dengan akuifer. Akuifer menurut BSN (2002) adalah lapisan batuan jenuh air di bawah permukaan tanah yang dapat menyimpan dan meneruskan air. Dilihat dari sifat media batuan tersebut tidak semua lapisan batuan terdapat airtanah. Ketidak terdapatnya airtanah pada suatu lapisan dipengeruhi oleh ukuran butir batuan yang pepat atau padat, sehingga tidak terdapat rongga antar butir (Singhal dan Gupta, 2010).

Zona tidak terdapatnya air tanah atau airtanah yang setempat dan terbatas dapat diperoleh dari distribusi daerah Cekungan Air Tanah (CAT) yang diterbitkan oleh Peraturan Pemerintah Energi Sumber Daya Mineral (Permen ESDM) nomor 2 tahun 2017 tentang Cekungan Air Tanah di Indonesia (Permen ESDM, 2017). Definisi cekungan airtanah adalah suatu wilayah yang dibatasi oleh batas hidrogeologik, tempat semua kejadian hidrogeologik seperti proses pengimbuhan, pengaliran dan pelepasan air tanah berlangsung (BSN, 2005; Permen ESDM, 2017). Sedangkan daerah non Cekungan Air Tanah (non CAT) dapat didefinisikan sebagai daerah tanpa adanya proses pengimbuhan, pengaliran dan pelepasan airtanah atau hanya terdapat akuifer bersifat lokal terbatas (Singhal dan Gupta, 2010; Dinas ESDM, 2011.). Sehingga kawasan tersebut sangat sedikit mendapat imbuhan airtanah yang salah satunya didominasi oleh faktor tektur tanah yang halus dan lekat (Purnama dkk, 2019).

Daerah non Cekungan Airtanah (Non CAT) diidentikkan dengan daerah kesulitan air atau kekeringan yang dipengruhi oleh kondisi geologi regional yatitu pada morfologi perbukitan lipatan, yang dipengaruhi oleh tektur lempung. Tektur tanah lempungan memiliki porositas 50$85 \%$, maka rongga antar butir untuk menyimpaan sangat rendah atau setempat maupun tidak ada dan memiliki potensi keterdapatan yang rendah (Todd and Mays, 2005; Fetter, 2014; Otto, 2017). Daerah non Cekungan Air Tanah (Non CAT) di Kabupaten Semarang, sebagian besar terdapat pada morfologi lipatan yang merupakan bagian dari Zona Kendeng. Zona Kendeng merupakan zona antilkinorium yang membentang barat-timur Bogor-Serayu Utara dan Kendeng (Robert dkk, 1975; DLH Kabupaten Semarang, 2018, ESDM, 2017a).

Mengacu pada Peta Cekungan Airtanah Permen ESDM no.2 tahun 2017, secara keruangan (spasial) berada di bagian timur dari CAT Ungaran dan CAT Salatiga (ESDM, 2017b; ESDM, 2017c; Republik Indonesia, 2017) atau secara administrasi berada di Kecamatan Ungaran Timur, Bergas, Pringapus, dan Bringin. Di Kecamatan Ungaran Timur, luas Cekungan Airtanah (CAT) yang terdiri dari CAT Semarang- Demak dan CAT Ungaran sebesar $26,31 \mathrm{~km}^{2}$ atau $47 \%$, sedangkan daerah Non CAT seluas $28,58 \mathrm{~km}^{2}$ atau $52 \%$, atau setengah lebih dari luas kecamatan Ungaran Timur yang terdapat kelangkaan airtanah (Gambar 1) (Dinas ESDM, 2011; ESDM, 2017b; ESDM, 2017c; DLH Kabupaten Semarang, 2018).

Pendekatan untuk mengetahui potensi airtanah dapat diperoleh dari pengukuran dan interpretasi geofisika dengan efektif dan dapat merepresentasikan kondisi didalam tanah (Milsom, 2003; Purnama dkk, 2013; Febriarta dkk, 2019). Metode yang populer digunakan antara pengukuran metode sesismik dengan pendekatan waktu tempuh gelombang, metode gravitasi dengan pendekatan perbedaan medan gravitasi, metode elektrik dengan resistivitas dengan pendekatan nilai konduktivitas elektrik, metode radar dengan pendekatan waktu tempuh (konstanta dielektrik) dan pendekatan elektrik dengan metode elektromagnetik, dengan pendekatan potensial elektrik yaitu sifat konduktivitas elektrik dan induksi (Milsom, 2003; Telford et all, 2004; Lowrie and William, 2007; Ungureanu, 2017).

Metode geofisika Electromagnetic Very Low Frequency (EM-VLF) didasarkan atas pengukuran dengan sifat konduktif yang tinggi. Sifat elektrik yang digunakan merupakan pancaran eletromagnetik pasif, dengan rentang frekuensi $0,5-40 \mathrm{kHz}$ (atau panjang gelombang dengan rentang hingga $20 \mathrm{~km}$ (Brayak, 1995; Purwanto, 2015). Nilai frekuensi Electromagnetic Very Low Frequency (EMVLF) dapat dihasilkan dari transduser atau penggetar hingga pada frekuensi tinggi yang diperlukan untuk mampu memberikan infromasi 


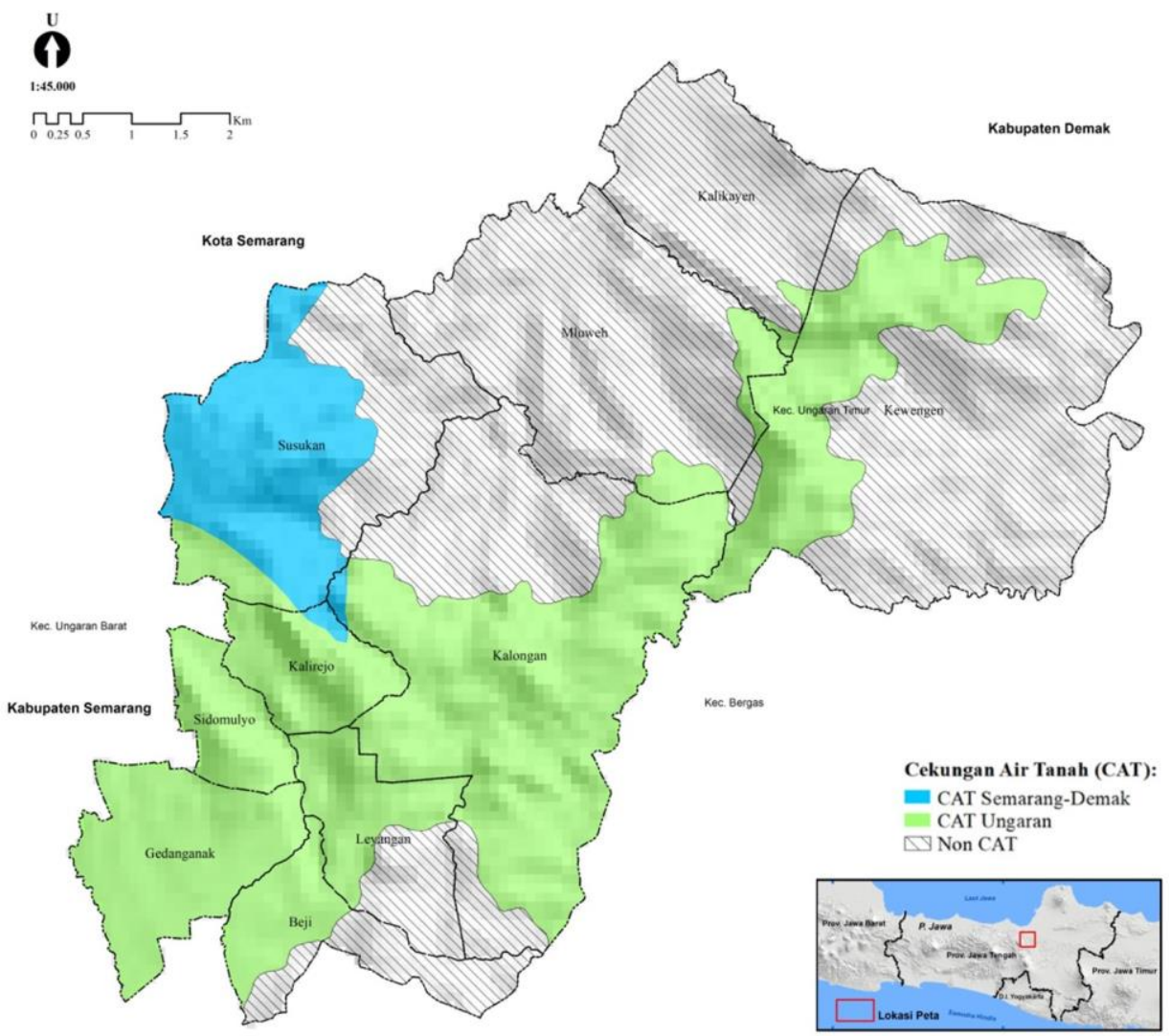

Gambar 1. Cekungan Airtanah (CAT) di Kecamatan Ungaran Timur (ESDM, 2017c)

setiap perlapisan atau rongga bawah tanah hingga startigrafi dibawah permukaan (Kearey, 2002: Santos, 2006 Hiskiawan, 2011, Shofyan dkk, 2016).

Dinas ESDM (2011) menyebutkan bahwa non CAT Ungaran Timur termasuk daerah kekeringan geologis, dengan potensi airatanah setempat hingga nihil yang dipengaruhi oleh litologi akuifer berupa lempungan dengan sifat akuitart. Neraca air penggunaan airtanah domestik (lokal) di kecamatan Ungaran timur mengalami defisit, sehingga pada musim kemarau mengalami kekeringan (DLH Kabupaten Semarang, 2018). Kekeringan di Kabupaten Semarang merupakan kekeringan hidrologis yang dipengaruhi oleh rendahnya cadangan air yang tersimpan yang dipengaruhi oleh faktor fisik lahan yang tidak mendukung (Neritarani, 2019). Berdasarkan laporan kekeringan oleh BPBD Kabupaten Semarang (2019) setiap tahun pada musim kemarau, Kecamatan Ungaran timur termasuk kekeringan sedang hingga tinggi. Berdasakan isu kekeringan tersbut didalam Rencana Pembangunan Jangka Menengah Daerah (RPJMD) Kabupaten Semarang Tahun 2016 - 2021, disebutkan upaya mitigasi kekeringan salah satunya adalah identifikasi dan pemetaan potensi air tanah (Perda Kabupaten Semarang, 2016). Salah satu langkah untuk mengetahui potensi tersebut adalah dengan aplikasi geofisika untuk pendugaan airtanah. Berdasarkan kemampuan penetrasi gelombang Very Low Frequency (VLF) yang dalam untuk interpretasi batuan dengan sifat pembawa air. Berdasarkan keunggulan aplikasi geofisika Very Low Frequency (VLF) maka tujuan dari penelitian ini adalah untuk mengetahui keterdapatan airtanah dan potensi airtanah dengan pendekatan debit airtanah di daerah airtanah langka atau yang berada di non CAT Ungaran timur.

\section{METODOLOGI}

\section{Penentuan Titik Pengukuran}

Lokasi atau titik pengukuran untuk mengetahui keterdapatan airtanah metode Electromagnetic Very Low Frequency (EMVLF) dengan purposive sampling atau pengambilan titik sampel yang mewakili daerah lembahan. Pengambilan titik sampel di daerah lembahan atau daerah yang lebih rendah, didasarkan pada pergerakan airtanah yang 
dipengaruhi oleh kontrol geologi (daerah perlipatan) memiliki kemiripan aliran permukaan dengan kondisi topografi (Singhal and Gupta, 2010; Fetter, 2014). Lokasi pengukuran disajikan pada Gambar 3. Kemudian untuk menghitung potensi airtanah diperoeh dengan perhutungan secara keruangan (spasial) dengan perangkat lunak Sistem Informasi Geografis (SIG). Keterbalan atau kemirigan gradien kontur air tanah diperoleh dari hasil interpretasi Electromagnetic Very Low Frequency (EM-VLF) yang kemudian dihitung luas wilayah (A) (rumus 1) dan nilai konduktivitas material dari Tabel 2.

\section{Interpretasi Airtanah dengan Electromagnetic Very Low Frequency (EM-VLF)}

Metode Electromagnetic Very Low Frequency (EM-VLF) untuk aplikasi pendugaan airtanah didasarkan pada pengukuran arus induksi yang berbanding lurus dengan nilai konduktivitas dari susunan lapisan batuan (Shofyan dkk, 2016). Gelombang yang yang dipancarkan transduser kedalam tanah untuk memberikan gelombang balik pada setiap perbedaan susuan batuan atau obyek yang ditangkap oleh sensor (Gambar 2). Sehingga nilai dari pengukuran, menghasilkan nilai konduktivitas (ms/s) dilapangan yang kemudian dikorelasikan dengan rentang nilai konduktifitas pada material batuan (Sismanto dan Hartantyo. 2005; Purwanto, 2015; Cahyadi dkk, 2016).

Gelombang induksi yang masuk kedalam tanah/batuan dari gelombang elektromagnetik mempunyai nilai yang timbul dari arus induksi
(Eddy current) dari material yang bersifat konduktif, sehingga mendapatkan persamaan untuk nilai konduktivitas dari persamaan konduktivitas batuan $(\sigma)(\mathrm{mho} / \mathrm{m})$, permivitas $(\varepsilon)$ $(\mathrm{H} / \mathrm{m})$ dan permeabilias $(\mu)(\mathrm{H} / \mathrm{m})$.

Persamaan elektromagnetik dalam perambatan gelombang yang digunkam persamaan Maxwell (Hiskiawan, 2011). Nilai pendekatan untuk mengetahui material batuan dan nilai konduktifitas dari pengukuran Electromagnetic Very Low Frequency (EMVLF), disajikan pada Tabel 1. Untuk merepresentasikan distribusi nilai terhadap susunan batuan dan keterdapatan airtanah disajikan secara keruangan (spasial) dengan perangkat lunak Sistem Informasi Geografis (SIG) dengan interpolasi terhadap nilai-nilai yang sama.

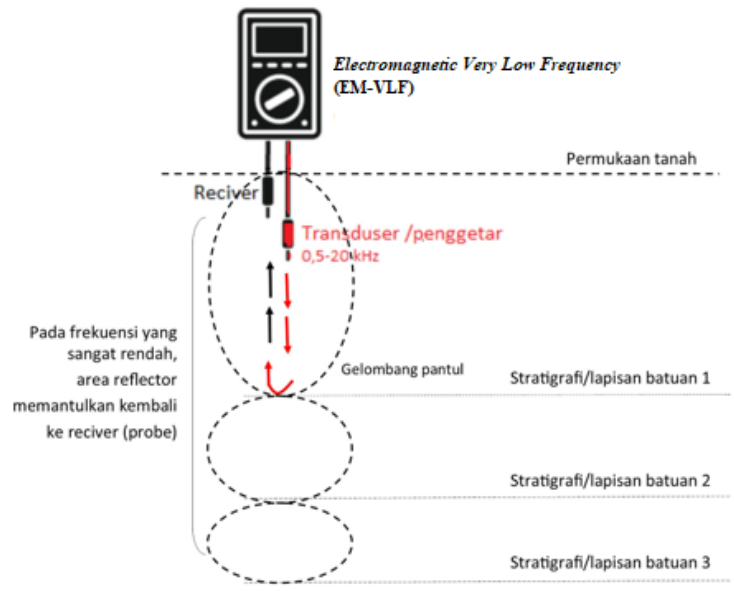

Gambar 2. Gelombang pantul Electromagnetic Very Low Frequency (EM-VLF) pada perlapisan batuan.

Tabel 1. Korelasi nilai konduktivitas $(\mathrm{ms} / \mathrm{m})$ dan daya hantar listrik pada setiap batuan (Loke, 2000; Purwanto, 2015; Jason dalam Cahyadi dkk, 2016)

\begin{tabular}{llll}
\hline Material Penyusun Batuan & Frekuensi EM-VLF (kHz) & Resistivitas $(\boldsymbol{\Omega} \mathbf{~ m})$ & \multicolumn{1}{c}{$\begin{array}{c}\text { Konduktivitas } \\
(\text { Siemens/m) }\end{array}$} \\
\hline Batubeku dan Metamorf & & $5 \times 10^{3}-10^{6}$ & $10^{-6}-2 \times 10^{-4}$ \\
Granit & $10-27$ & $10^{3}-10^{6}$ & $10^{-6}-10^{-3}$ \\
Basal & & $6 \times 10^{2}-4 \times 10^{7}$ & $2,5 \times 10^{-8}-1,7 \times 10^{-3}$ \\
Marmer & & \\
Kuarsa & & $10^{2}-2 \times 10^{8}$ & $5 \times 10^{-9}-10^{-2}$ \\
Batu Sedimen & $15-25$ & $8^{-4} \times 10^{3}$ & $2,5 \times 10^{-4}-0,125$ \\
Batupasir & & $20^{-2} \times 10^{3}$ & $5 \times 10^{-4}-0,05$ \\
Serpih & $50^{-4} \times 10^{2}$ & $2,5 \times 10^{-3}-0,02$ \\
Batugamping & & \\
Tanah dan air & & $1-100$ & $0,01-1$ \\
Lempung & $0,2-20$ & $10-800$ & $1,25 \times 10^{-3}-0,1$ \\
Aluvium & & $10-100$ & $0,01-0,1$ \\
Air tanah (tawar) & $<0,2$ & 5 \\
Air laut (asin) & & & \\
\hline
\end{tabular}




\section{Perhitungan Potensi Debit Airtanah Pendekatan Darcy}

Debit airtanah merupakan jumlah volume zat cair (airtanah) yang mengalir dalam satuan waktu yang dinyatakan dalam liter/detik atau satuan meter kubik $\mathrm{m}^{3} / \mathrm{jam}$ (BSN, 2005). Untuk mengetahui potensi airtanah, menggunakan rumus pendekatan Darcy (Todd and Mays, 2005), sebagai berikut:

$$
\mathrm{Q}=\mathrm{K} \text {. i. A }
$$

dimana,

$$
\begin{aligned}
& \mathrm{Q}: \text { Debit airtanah }\left(1 / \mathrm{d} \text { atau } \mathrm{m}^{3} / \mathrm{jam}\right) \\
& \mathrm{K}: \text { Konduktivitas hidrolik (kelulusan) } \text { ( } \mathrm{m} / \text { hari), persamaan dari Tabel } 2 . \\
& \mathrm{i}: \begin{array}{l}
\text { Gradien hidrolika / landaian hidrolik / } \\
\text { kemiringan muka air tanah }(\mathrm{dh} / \mathrm{dl})
\end{array} \\
& \mathrm{A}: \text { Luas penampang hidrogeologi arah aliran }
\end{aligned}
$$

Nilai konduktivitas hidrolik / permeabilitas (K) merupakan nilai atau tingkat pergerakan air mengalir didalam tanah/batuan dengan satuan waktu $\mathrm{m} /$ detik atau $\mathrm{m} / \mathrm{hari}$ (BSN, 2005). Nilai konduktivitas hidrolik dalam perhitungan Darcy (1), ditampilkan dalam Tabel 2. Untuk menampilkan daerah/wilayah potensi airtanah disajikan dalam pengkelasan kuantitas air (debit airtanah) mengacu Standarisasi Nasional Indoneisa (SNI) tentang penyelidikan potensi airtanah skala 100.000 (BSN, 2005), yaitu kelas tinggi dengan nilai kuantitas besar (tinggi) dengan debit >10 liter/detik, sedang dengan debit 2-10 liter/detik, rendah dengan debit $<2$ liter/detik dan nihil jika tidak terdapat nilai debit.

\section{HASIL}

\section{Airtanah di Non Cekungan Air Tanah (Non CAT)}

Hasil Pengukuran dengan Electromagnetic Very Low Frequency (EM-VLF) ditunjukkan dalam konduktivitas dengan satuan $(\mathrm{ms} / \mathrm{s})$ dengan rentang nilai 1-140 ms/s. Berdasarkan hasil pengukuran di daerah non CAT Ungaran timur, diketahui bahwa nilai terendah $1 \mathrm{~ms} / \mathrm{s}$ berkorelasi (Tabel 2) dengan nilai pada material penyusun endapan lanau, sedangkan nilai tertinggi sebesar $140 \mathrm{~ms} / \mathrm{s}$ berkorelasi dengan lempung hingga batulempung. Pada bagian utara didominasi oleh nilai konduktivitas 100-120 $\mathrm{m} / \mathrm{s}$. Nilai tersebut berkorelasi dengan material batuan berupa batupasir dan lempung. Sedangkan pada bagian selatan nilai konduktivitas didominasi dengan nilai
Tabel 2. Nilai Konduktivitas Hidrolik (Todd dan

\begin{tabular}{lc}
\multicolumn{2}{c}{ Mays, 2005) } \\
\hline \multicolumn{1}{c}{ Koterial batuan } & $\begin{array}{c}\text { Hidrolik (m/vitas } \\
\text { Kari) }\end{array}$ \\
\hline Kerikil, kasar & 150 \\
Kerikil, sedang & 270 \\
Kerikil, halus & 450 \\
Pasir, kasar & 45 \\
Pasir, sedang & 12 \\
Pasir, halus & 2,5 \\
Lanau & 0,08 \\
Tanah liat & 0,0002 \\
Batu pasir, berbutir halus & 0,2 \\
Batu pasir, berbutir sedang & 3,2 \\
Batugamping & 0,94 \\
Dolomit & 0,001 \\
Gumuk Pasir & 20 \\
Loess / pengendapan & 0,08 \\
lumpur & 5,7 \\
Gambut & 0,2 \\
Skis / batuan metamorf & 0,00008 \\
Slate /batuan metamorf & 0,49 \\
halus & 30 \\
Till sedimen, pasiran & 0,2 \\
Till sedimen, berkerikil & 0,01 \\
Tuff & 0,2 \\
Basal & 1,4 \\
Gabbro, lapuk & \\
Granit, lapuk & \\
\hline &
\end{tabular}

10-43 ms/s. Nilai tersebut berkorelasi dengan batuanbeku dan batupasir.

Kecamatan Ungaran Timur terdapat 2 CAT, yaitu: CAT Ungaran yang berada di Formasi Breksi Gunungapi $(\mathrm{Qb})$, dan CAT SemarangDemak berada di Formasi Batuan Gunungapi Tak Terpisahkan (Qvu). Sedangkan non CAT Ungaran Timur bagian utara berada di formasi Kerek (Tmk) dan Formasi Kalibeng (Tpmk). Non CAT Ungaran Timur bagian selatan berada di formasi breksi gunungapi (Qvb) bagian dari gunung Mergi. Menurut Robert dkk, (1975) lokasi pengukuran (non CAT Ungaran timur) merupakan bagian dari Formasi Kerek (Tmk) yang tersusun atas perselingan batulanau, batulempung, batupasir gampingan dan batugamping dan Formasi Kalibeng (Tpmk) yang tersusun atas napal pejal, napal bersisipan batupasir tufan dan batugamping dan Formasi Breksi Gunungapi (Qvb) tersusun atas batuan breksi gunungapi, konglomerat dan batupasir tufan.

Hasil pengukuran litologi akuifer keterdapatan air tanah menunjukkan hasil yang sesuai dengan formasi penyusun litologi, dengan 
ciri banyak dicirikan dengan perselingan batupasir dan pasiran di daerah non CAT Ungaran timur bagian selatan, sedangkan bagian utara dicirkan dengan litologi akuifer pasir lempungan. Distribusi nilai konduktivitas ( $\mathrm{ms} / \mathrm{s}$ ) di daerah non CAT disajikan pada Gambar 3.

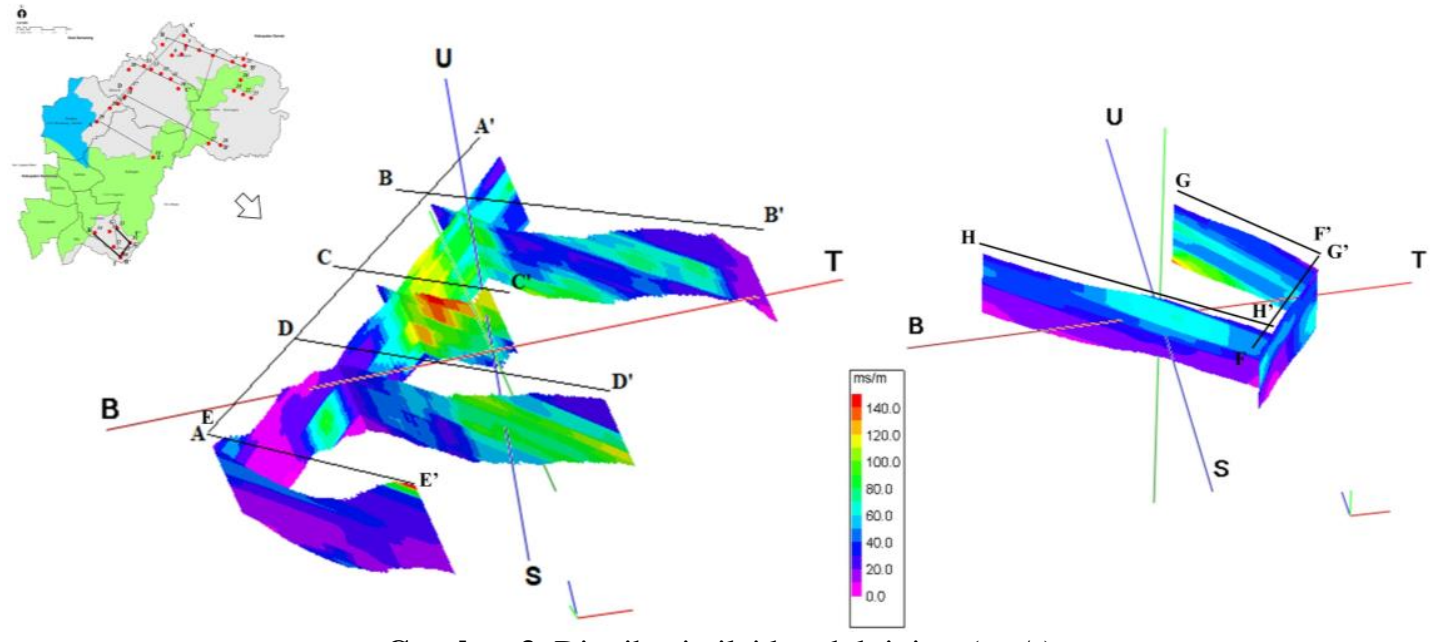

Gambar 3. Distribusi nilai konduktivitas ( $\mathrm{ms} / \mathrm{s})$

Tabel 3. Potensi keterdapatan Airtanah

\begin{tabular}{|c|c|c|c|c|c|c|}
\hline Kode & $\mathbf{X}$ & $\mathbf{Y}$ & Elevasi $(\mathbf{Z})$ & Kedalaman (m) & Litologi Akuifer & Debit (m³/jam) \\
\hline 1 & 443257 & 9216141 & 133 & $55-77$ & Batupasir & 1,4 \\
\hline 2 & 442822 & 9216035 & 143 & $15-25$ & Batupasir & 1,0 \\
\hline 3 & 442020 & 9216283 & 115 & $55-77$ & Batupasir & 1,0 \\
\hline 4 & 441471 & 9216502 & 88 & $77-90$ & Batupasir & 1,0 \\
\hline 5 & 440930 & 9216680 & 65 & $44-50$ & Batupasir & 1,0 \\
\hline 6 & 440844 & 9217089 & 66 & $90-100$ & Batupasir & 1,0 \\
\hline 7 & 439981 & 9216723 & 63 & $50-80$ & Batupasir & 1,0 \\
\hline 8 & 440366 & 9216291 & 65 & Tidak ada & Tidak ada & Tidak ada \\
\hline 9 & 440758 & 9216337 & 60 & $55-90$ & Batupasir & 1,0 \\
\hline 10 & 440621 & 9214950 & 185 & $0-15$ & Pasir lempungan & 2,0 \\
\hline 11 & 440315 & 9215340 & 118 & $0-16$ & Pasir lempungan & 1,0 \\
\hline 12 & 439921 & 9215551 & 103 & Tidak ada & Tidak ada & Tidak ada \\
\hline 13 & 439522 & 9215731 & 74 & $0-30$ & Lempung pasiran & 1,0 \\
\hline 14 & 439603 & 9212174 & 301 & $40-86$ & Pasir & 2,0 \\
\hline 15 & 439238 & 9215867 & 72 & $0-15$ & Pasir lempungan & 2,4 \\
\hline 16 & 438614 & 9215715 & 104 & $70-90$ & Batupasir & 1,4 \\
\hline 17 & 438691 & 9214951 & 88 & $77-88$ & Batupasir & 2,0 \\
\hline 18 & 438448 & 9214611 & 125 & $40-90$ & Batupasir & 2,4 \\
\hline 19 & 438180 & 9214335 & 159 & $44-63$ & Batupasir & 4,0 \\
\hline 20 & 437850 & 9214163 & 154 & $0-27$ & Pasir lempungan & 2,8 \\
\hline 21 & 443306 & 9215877 & 142 & $88-132$ & Batupasir & 1,2 \\
\hline 22 & 443253 & 9214712 & 235 & Tidak ada & Tidak ada & Tidak ada \\
\hline 23 & 438143 & 9209329 & 377 & $71-140$ & Batupasir & 3,4 \\
\hline 24 & 442880 & 9214866 & 216 & $70-72$ & Batupasir & 1,0 \\
\hline 25 & 443574 & 9214572 & 204 & Tidak ada & Tidak ada & Tidak ada \\
\hline 26 & 443152 & 9215300 & 199 & Tidak ada & Tidak ada & Tidak ada \\
\hline 27 & 441851 & 9212736 & 298 & $44-63$ & Batupasir & 1,0 \\
\hline 28 & 442338 & 9212670 & 214 & Tidak ada & Tidak ada & Tidak ada \\
\hline 29 & 437320 & 9213614 & 210 & $62-111$ & Pasir & 3,4 \\
\hline 30 & 438278 & 9208142 & 457 & $60-90$ & Pasir & 3,2 \\
\hline 31 & 438368 & 9208303 & 432 & $28-48$ & Batupasir tuffan & 5,0 \\
\hline 32 & 438000 & 9208573 & 431 & $76-110$ & Batupasir & 5,0 \\
\hline 33 & 438667 & 9208740 & 403 & $28-30$ & Batupasir & 1,0 \\
\hline 34 & 437244 & 9209146 & 387 & $25-44$ & Batupasir tuffan & 5,0 \\
\hline 35 & 437838 & 9209194 & 370 & $22-40$ & Batupasir tuffan & 4,0 \\
\hline
\end{tabular}




\section{Potensi Debit Airtanah}

Potensi debit airtanah di daerah non CAT secara umum berada pada material pasiran. Berdasarkan korelasi nilai konduktivititas, terdapat pada empat (4) lapisan batuan yaitu batupasir, pasir lempungan, pasir, dan batupasir tufan. Keterdapatan airtanah pada Non Cekungan Airtanah (Non CAT) bagian utara didominasi oleh litologi akuifer batupasir dengan kedalaman rata-rata $10 \mathrm{~m}$ dibawah permukaan tanah. Sedangkan litologi akuifer di bagian selatan didominasi oleh batupasir tufan dengan kedalaman rata-rata $25 \mathrm{~m}$ dibawah permukaan tanah. Berdasarkan hasil pengukuran dan analisis keterdapatan airtanah, terdapat 6 dari 53 titik pengukuran tidak ditemukan airtanah. Tidak ditermukannya airtanah dipengaruhi oleh penyusun lapisan batuan berupa lempung. Nilai potensi keterdapatan airtanah di daerah Non Cekungan Airtanah (Non CAT) disajikan pada Tabel 3.

\section{PEMBAHASAN}

\section{Airtanah di Non Cekungan Airtanah (Non CAT)}

Hasil dari pengukuran, menunjukkan bahwa pada bagian utara tersusun atas lempung pasiran, pasir, batupasir, lempung dan lanau. Berdasarkan penelitian, keterdapatan airtanah berada pada lapisan material pasiran, antara lain lempung pasiran, pasir dan batupasir, seperti pada penampang A-A' (Gambar 4). Sehingga litologi akuifer berada pada material pasir lempungan. Sifat dari akuifer airtanah bersifat lokal atau tidak berhubungan dengan sistem airtanah yang lain, seperti yang ditunjukkan pada titik 29, 20 dan 19 di Desa Susukan. Hal tersebut kemungkinan disebabkan oleh lapisan lempung yang membuat disekitar akuifer pasiran menjadi kedap air sehingga bersifat lokal atau setempat.

Berdasarkan lokasi keterdapatan airtanah pada kedalaman 5 - $100 \mathrm{~m}$ dibawah permukaan, dapat disimpulkan daerah non CAT banyak terdapat akuifer tertekan dengan potensi airtanah yang rendah dengan ketebalan akuifer yang $<5 \mathrm{~m}$ seperti pada titik $07,18,15,17$ dan 20 pada Gambar 4 dan pada penampang B-B' pada titik 02, 03 pada Gambar 5. Potensi airtanah terbesar pada berada di titik 18 pada lapisan akuifer tertekan pada material pasir kasar dengan potensi airtanah $4 \mathrm{~m}^{3} / \mathrm{jam}$ atau 1,11 liter/detik. Pada bagian morfologi lembah memiliki potensi airtanah hingga $1,4 \mathrm{~m}^{3} / \mathrm{jam}$ seperti pada titik 05 , 06, 07 dan 08 (Gambar 4 dan Gambar 5). Keterdapatan akuifer tertekan terdapat pada kedalaman 39-77 $\mathrm{m}$ dibawah permukaan tanah, debit airtah tertekan rata-rata $1 \mathrm{~m}^{3} / \mathrm{jam}$ atau 0,27 liter/detik. Keterdapatan air tanah pada bagian selatan, berada pada lapisan litologi akuifer berupa batupasir tuffan dengan sisipan pasir. Berdasarkan perhitungan potensi debit airtanah, dapat disimpulkan bahwa daerah ini memiliki potensi airtanah yang rendah baik pada akuifer tidak tertekan. Potensi airtanah dengan debit tertinggi berada pada titik 31 dan 32, dengan nilai $5 \mathrm{~m}^{3} / \mathrm{jam}$ atau 1,3 liter/detik pada akuifer bebas pada material pasiran. Debit rata-rata pada akuifer bebas sebesar $3 \mathrm{~m}^{3} / \mathrm{jam}$ atau 0,83 liter/detik pada material pasir seperti yang ditunjukkan pada titik 32 (Gambar 6).

\section{Potensi Airtanah}

Potensi airtanah disajikan dalam nilai debit airtanah, berdasarkan perhitungan, potensi debit tertinggi adalah $1,3 \mathrm{l} /$ detik atau $5 \mathrm{~m}^{3} / \mathrm{jam}$ (Titik 31, 32 dan 34) yang berada diatas formasi Breksi Gunung Api (Qvb) atau secara administrasi berada di Desa Beji dan Leyangan (bagian selatan kecematan Ungaran Timur). Menurut Said dan Sukrisno (1988) daerah Non Cekungan Airtanah (Non CAT) termasuk kedalam daerah akuifer produktivitas kecil setempat dam daerah airtanah langka.

Berdasarkan pengukuran dan analisis potensi debit diketahui debit tertinggi $(1,3$ 1/detik atau 5 $\left.\mathrm{m}^{3} / \mathrm{jam}\right)$ termasuk kelas kecil setempat dan nihil dikarenakan nilai pengkelasan debit kecil yaitu nilai $<21 /$ detik atau $<7,2 \mathrm{~m}^{3} / \mathrm{jam}$. Sedangkan pada bagian utara nilai tertinggi dengan debit $1,11 \mathrm{l} /$ detik atau $4 \mathrm{~m}^{3} / \mathrm{jam}$ (Titik 19) yang berada diatas formasi Kerek yang tersusun atas perselingan batulempung, batupasir dan pasiran. Litologi akuifer tersebut tersusun atas batupasir (Gambar 4). Distribusi potensi debit airtanah di daerah Non Cekungan Airtanah (Non CAT) disajikan pada Gambar 7. 


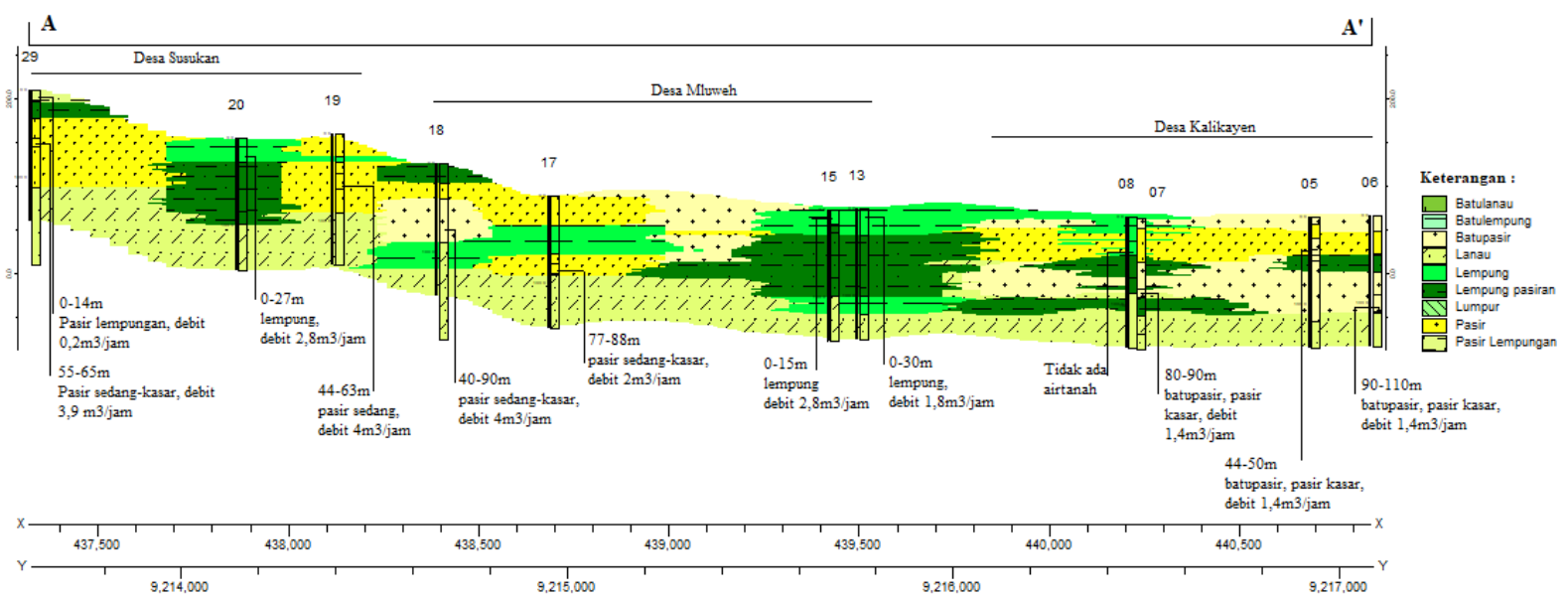

Gambar 4. Keterdapatan airtanah pada profil A-A' bagian utara

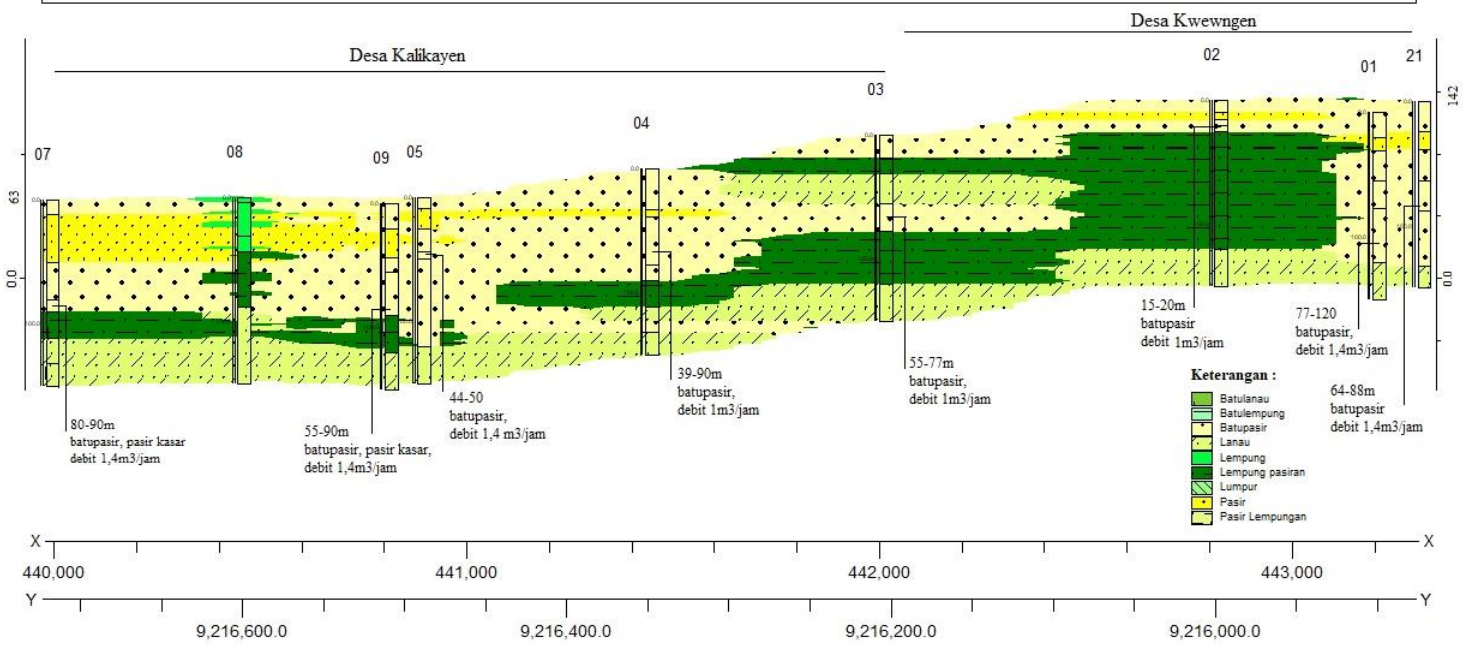

Gambar 5. Keterdapatan airtanah pada profil B-B‘ bagian utara

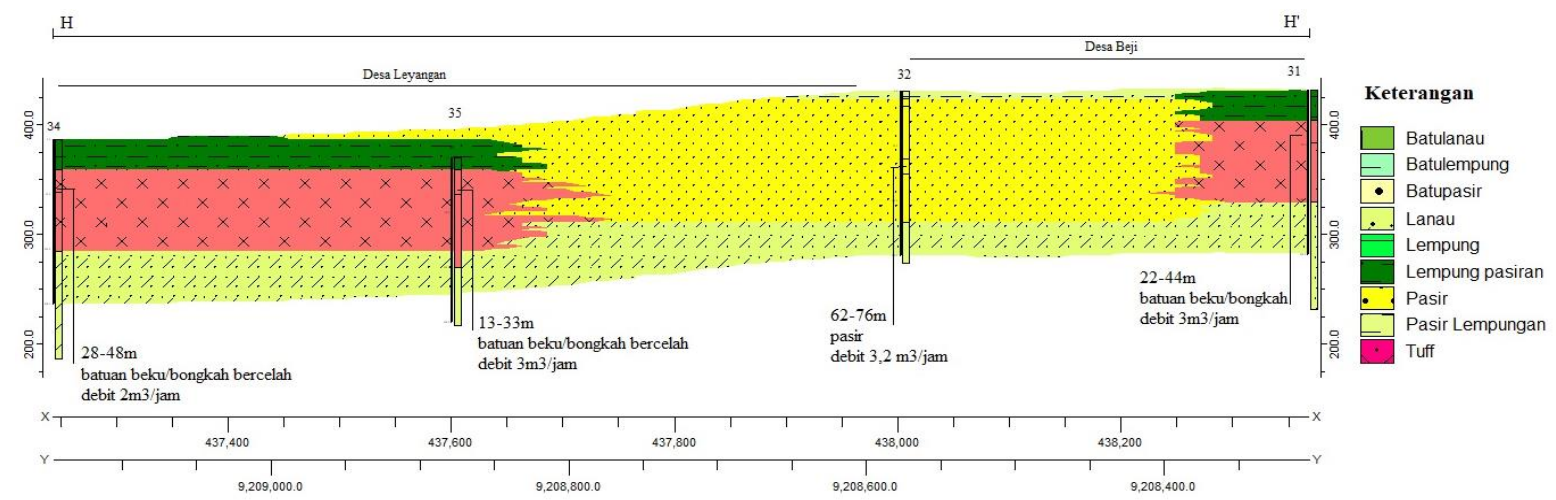

Gambar 6. Keterdapatan airtanah pada profil H-H` bagian selatan 


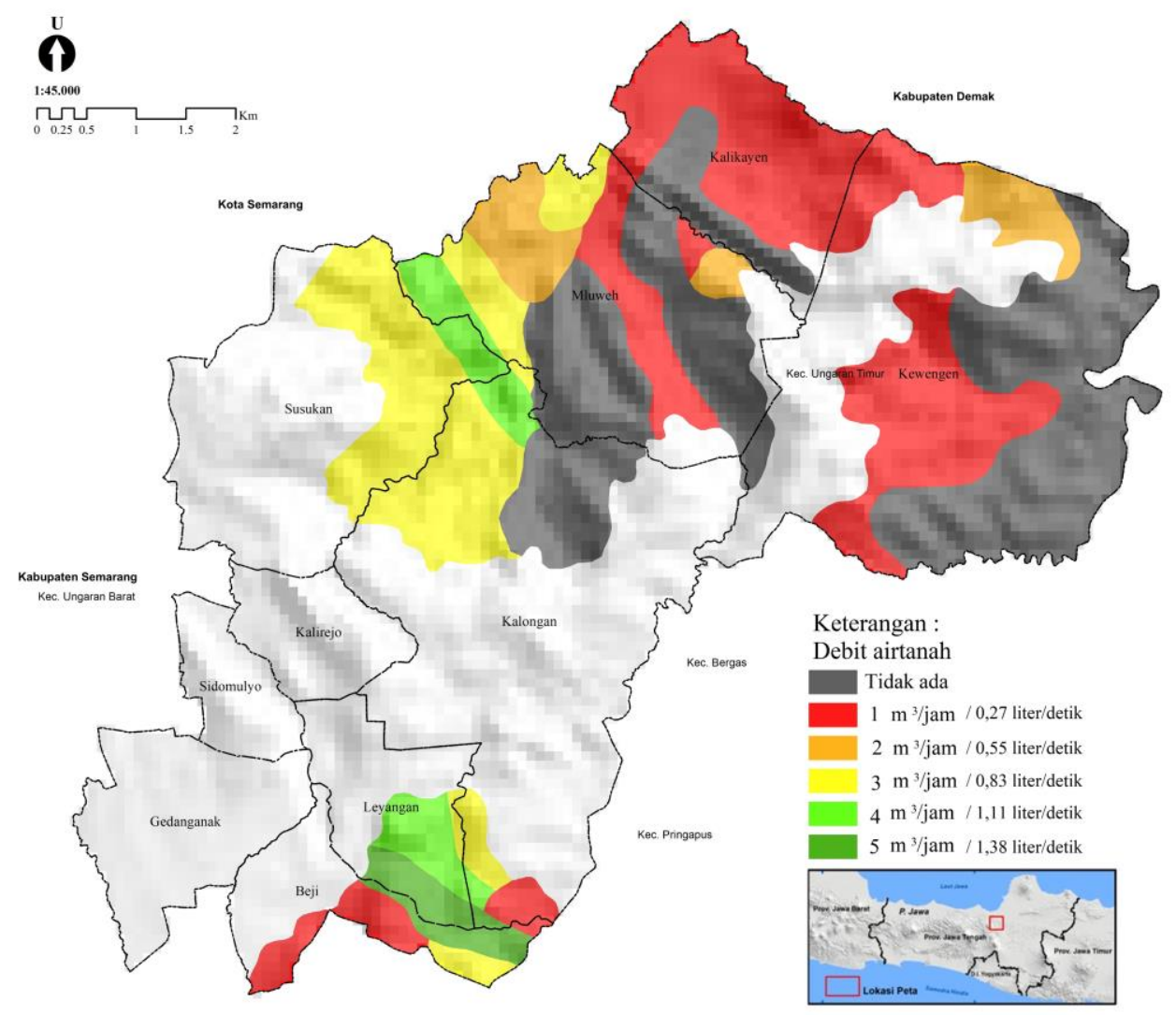

Gambar 7. Sebaran Potensi Debit Airtanah

\section{KESIMPULAN}

Di daerah penelitian terdapat dua daerah non CAT yaitu bagian utara dan bagian selatan. Non CAT di bagian utara, airtanah berada pada kedalaman rata-rata $10 \mathrm{~m}$ dengan material penyusun liologi akuifer berupa batupasir dengan perselingan lempung. Potensi debit airtanah rata-rata sebesar $1 \mathrm{~m}^{3} / \mathrm{jam}$ atau 0,27 liter/detik. Sedangkan daerah non CAT bagian selatan berada pada kedalaman rata-rata $25 \mathrm{~m}$ dengan penyusun litologi akuifer berupa batupasir tuffan perselingan pasir. Potensi debit airtanah sebesar 1,3 1/detik atau $5 \mathrm{~m}^{3} / \mathrm{jam}$. Keterdapatan airtanah membentuk akuifer dengan sifat lokal atau terbatas setempat, yang dibatasi oleh lapisan kedap airtanah berupa lempung. Potensi airtanah tersebut termasuk kedalam kelas debit kecil.

\section{UCAPAN TERIMA KASIH}

Ucapan terima kasih disampaikan kepada Dinas Lingkungan Hidup (DLH) Kabupaten Semarang yang telah memfasilitasi penelitian ini.

\section{DAFTAR PUSTAKA}

Badan Penanggunalan Bencana Daerah (BPBD) Kabupaten Semarang, 2019. Laporan Kebencanaan Kabupaten Semarang. Badan Penanggulangan Bencana Daerah (BPBD) Kabupaten Semarang. Ungaran.

Badan Standardisasi Nasional, 2002. Standar Nasioanl Indonesia No.19-6728.1-2002. Penyusunan Neraca Sumber Daya Bagian 1: Sumber daya air spasial. Badan Standardisasi Nasional: Jakarta.

Badan Standardisasi Nasional, 2005. Standar Nasioanl Indonesia No.13-7121-2005. Penyelidikan Potensi Air Tanah Skala 1:100.000. Badan Standardisasi Nasional: Jakarta.

Bayrak, M. 1995. Use of Electromagnetic VLF Method in Shallow Exploration in Turkey (in Turkish). Jeofizik, 9-10, 143-148.

Dinas Energi dan Sumber Daya Mineral (Dinas ESDM), 2011. Penyusunan Zona Pemanfaatan dan konservasi Air Tanah Pada Cekungan Air Tanah (CAT) Ungaran. Laporan Akhir. Dinas Energi dan Sumber Daya Mineral (Dinas ESDM):Semarang. 
Dinas Lingkungan Hidup (DLH) Kabupaten Semarang, 2018. Katersediaan Air Bawah Tanah di Kabupaten Semarang. Laporan Akhir. Dinas Linkungan Hidup Kabupaten Semarang: Ungaran.

Febriarta, E., Suswanti, Noviandaru, S. 2019. Interpretasi Electrical Resitivity Tomography Untuk Pendugaan Air Tanah Dangkal Pada Formasi Gunungapi Muda. Jurnal Nasional Teknologi Terapan. 3(1). 49-62.

Fetter, C.W., 2014. Applied Hydrogeology Fourth Edition. Pearson New International Education: England.

Hiskiawan, P. 2011. Akuisisi Data VLF-EM Menggunakan Teknik Konvensional dan Teknik Gradio. Jurnal Fisika Himpunan Fisika Indonesia, 11 (1).18-22.

Kearey, Philip. 2002. An Intoduction to Geophysical Exploation. Third Edition. USA : Blackwell Science Ltd.

Lowrie, W., 2007. Fundamental of Geophysics (2nd ed.). New York: Cambridge University Press.

Menteri Energi dan Sumber Daya Mineral (ESDM), 2017a. Litologi Akuifer. 31 Mei 2017. Diakses pada 5 Mei 2020. https://geoportal.esdm.go.id/geologi.

Menteri Energi dan Sumber Daya Mineral (ESDM), 2017b. Produktivitas Air Tanah. 31 Mei 2017. Diakses pada 5 Mei 2020. https://geoportal.esdm.go.id/geologi.

Menteri Energi dan Sumber Daya Mineral (ESDM), 2017c. Cekungan Air Tanah. 31 Mei 2017. Diakses pada 5 Mei 2020. https://geoportal.esdm.go.id/geologi.

Milsom, J., 2003. Field Geophysics, The Geological Field Guide Series (3rd ed.). London: West Sussex: John Wiley \& Sons.

Neritarani, R., 2019. Identifikasi Dan Strategi Mitigasi Bencana Kekeringan Potensial Di Kabupaten Semarang. Jurnal Plano Madani, 8(1). 72-84.

Otto, D.L.S. 2017. Analytical Groundetare Mechanics. Cambridge University Press. United Kingdom.

Peraturan Daerah Kabupaten Semarang Nomor 15 Tahun 2016. 2016. Rencana Pembangunan jangka Menegah daerah (RPJMD) Kabupaten Semarang Tahun 20162021.

Purnama, S., Febriarta, E., Cahyadi, A., Khakhim, N., Ismagil, L., Prihatno, H., 2013. Analisis Karakteristik Akuifer Berdasarkan
Pendugaan Geolistrik di Pesisir Kabupaten Cilacap jawa Tengah. Jurnal Geografi, 11(22).155.165

Purnama, S., Tivinton, T.A., Cahyadi, A., Febriarta, E., 2019. Kajian Daerah Imbuhan Airtanah di Kabupaten Ngawi. Jurnal Geografi, 16(1).54-59.

Purwanto, E.H., 2015. Aplikasi Metode Very Low Frequency Electromagnetic (Vlf-Em) Untuk Karakterisasi Bawah Permukaan Di Daerah Kapur Desa Melirang Kecamatan Bungah Kabupaten Gresik. Tesis. Program magister Bidang Keahlian Fisika Bumi Jurusan Fisika Fakultas Matematika dan Ilmu Pengetahuan Alam Institut Teknologi Sepuluh November: Surabaya.

Said, H.D. dan Sukrisno, 1988. Peta Hidrogeologi Indonesia. Direktorat Geologi dan Tata Lingkungan: Bandung Santos, F.A.M. 2006. Instructions for Running PrepVLF and Inv2DVLF 2-D Inversion of VLF EM Single Frequency. Centro de Geofisica da Universidade de Lisboa, Portugal.

Shofyan, M.S., Hilyah A., Rachman, J.P.G.N., 2016. Penerapan Metode Very Low Frequency Electromagnetic (VLF-EM) Untuk Mendeteksi Rekahan pada Daerah Tanggulangin, Sidoharjo. Jurnal Geosaintek. 2(2).129-134.

Singhal, B.B.S. dan Gupta, R.P., 2010. Applied Hydogeology of Fracture Rock. Springer Dordrecht Heidelberg London: Springer.

Sismanto dan Hartantyo, E., 2005. Distribution of Leachate Polution in The Final Disposal of Piyungan, Bantul, Yogyakarta, by Using The Electromagnetic Method. Proceedings Joint Convention Surabaya. 110-115. https://doi.org/10.1063/1.4990895

Telford, W. M., Geldart, L. P., Sheriff, R. E., 2004. Applied Geophysics (2nd ed.). London: Cambridge University Press.

Thaden, R.E., Sumadirdja, H., Richards, P.W., 1975. Peta Geologi Lembar Magelang dan Semarang. Direktorat Geologi: Bandung.

Todd, D.K. dan Mays, L.W., 2005. Groundwater Hydrology 3rd Edition. Denver: John Wiley \& Sons. Inc.Lewis, R. dan Davis, A., 1989. Reflectance anisotropy of Carboniferous coals in the Appalachian Foreland Basin, Pennsylvania, U.S.A. International Journal of Coal Geology, 13, hal.341-373. 
Ungureanu, C., Priceputu, A., Bugea, A. L., Chirică, A., 2017. Use of electric resistivity tomography (ERT) for detecting underground voids on highly anthropized urban construction sites. Procedia Engineering, 209,

202-209.

https://doi.org/10.1016/j.proeng.2017.11.148 